УДК: 372.881 .1

DOІ: 10.22363/2313-2299-2017-8-2-479-484

\title{
ACCESS TO SECOND LANGUAGE ACQUISITION
}

\author{
Mahmoud Mustafa H. Jabballa \\ RUDN University \\ 6, Miklukho-Maklaya str., Moscow, Russia, 117198
}

\begin{abstract}
This paper discusses the different views on the availability of UG principles in language acquisition of adult second language learners, and summarizes some of the evidence for or against each position. One important issue in current language acquisition research is whether the acquisition of a second language is fundamentally different from that of the first language. Researchers approaching second language acquisition (SLA) from the linguistic perspective often relate this issue to the availability of Universal Grammar to second language acquisition. Universal Grammar (UG) refers to a grammar which is genetically endowed to all human beings and which all languages have in common.
\end{abstract}

Key words: Universal grammar, language acquisition, availability, hypothesis, fundamental identity/difference

\section{INTRODUCTION}

One important issue in current language acquisition research is whether the acquisition of a second language is fundamentally different from that of the first language. Researchers approaching second language acquisition (SLA) from the linguistic perspective often relate this issue to the availability of Universal Grammar (UG) to second language acquisition. Universal Grammar (UG) refers to a grammar which is genetically endowed to all human beings and which all languages have in common. If second language learners have access to Universal Grammar, grammar of the second language (L2) would not be fundamentally different from that of the first language (L1), which is guided by UG. There have been many debates about whether UG plays a role in second language acquisition. Two opposing views are commonly suggested: 'The Fundamental Difference Hypothesis' by Bley-Veroman (1989), and The 'Fundamental Identity Hypothesis' by Schwartz $(1987,1997)$.

\section{THE FUNDAMENTAL DIFFERENCE HYPOTHESIS}

This view claims that the nature of the process involved in second language acquisition is radically different from primary language acquisition. Whereas the former process involves a language-specific faculty, the LAD, the latter observes a more general problem-solving skill, also typical of adult learning in various fields other than language. Bley-Vroman's (1989) specific proposal is that: "The function of the domain specific acquisition system is filled in adults (though indirectly and imperfectly) by this native language knowledge and by general abstract problem-solving system. I shall call this proposal the Fundamental Difference Hypothesis" [Bley-Vroman's 1989: 50]. In support 
of this claim, he reports nine areas of learning difficulties among adults such as lack of success, general failure, variation in success, fossilization, which make adult second language learning acquisition more similar to general adult problem-solving than to child language development.

\section{THE FUNDAMENTAL IDENTITY HYPOTHESIS}

This hypothesis is consistent with the idea that the same language-specific mechanism guiding L1 acquisition may be involved in L2 acquisition as well. Although very seldom, some adult second language learners achieve native speaker competence, and this fact requires an explanation. It might well be that the LAD is available to second language learners well beyond the critical period. Ellis (1994) cites Dulay and Burt (1974), Bailey, Madden, and Krashen (1974), d'Anglejan and Tucker (1975) and others as saying that second language acquisition is, in crucial respects, like first language acquisition, and the same theoretical constructs can be invoked to explain both. As they showed, developmental L2 errors tend to mimic those committed by the L1 learner, and, with respect to the morpheme studies, the order of acquisition of certain morpheme in L2 mirrors that in L1. Although the L2 morpheme acquisition studies are not unproblematic, they, along with other evidence, resulted in a new consensus about L2 acquisition, namely that UG might not shut off at puberty. At the same time, evidence was brought up that an L2 learner's grammar, far from being a mere malgamate of deviant forms, itself obeys the crucial properties of naturally occurring human languages, subject to the same principles of organization and constraints [Ellis 1994].

Schwartz (1997) also presents evidence in favor of the Fundamental Identity Hypothesis by comparing acquisition sequences of child and adult second language learners who share a similar language background. Schwartz maintains that: "The result of the comparison between the developmental sequences of adult and child L2A lend support to the hypothesis that linguistic-specific mechanisms do drive nonnative grammar construction" [Schwartz 1997:15].

\section{ON THE UG ACCESSABILITY}

Generally there are four different positions as to the accessibility of UG to SL learners. Those include:

1. No access position: there is no such thing as UG.

2. Indirect access position: UG exists, but second language learners only have indirect access to it via.

3. Partial access position: UG exists, but L2 learners only have partial access to it.

4. Full access position: second language learners have full access to UG.

As for hypothesis one, some people like O'Grady [O'Grady 1996; cited in White 2003] see no need to postulate a language module, and no need to look for linguistic universals either.

The best-known hypothesis regarding the second position, that UG exists, but that second language learners only have indirect access to it, is Bley-Vroman's Fundamental Difference Hypothesis [Bley-Vroman 1989]. 
Bley-Vronan argues that the mind is modular, and that there exists a language faculty (UG), which is essential for the development of $\mathrm{L} 1$, but that $\mathrm{UG}$ is not directly at, works in SLA. According to Bley-Vroman, adult second language learners do not have direct access to UG; what they know of universals is constructed through their L1, and they then have to use general problem solving abilities, such as those that operate in non-modular learning tasks: hypothesis testing, inductive and deductive reasoning, analogy, etc.

Gregg (1996) says of those who adopt this approach: "Superficially it might seem that they want it both ways: if the learner succeeds, it is because of UG via the L1, if the learner fails it is because UG is not available. But in fact the claims are more precise. (...). If a given L2 instantiates a principle not instantiated in the L1, that principle will not be acquired, and if the L2 setting of a given parameter is more restrictive than the L1 setting, it will not be acquired, in the absence of negative evidence [Gregg 1996: 65].

The third hypothesis, partial access, claims that L2 learners have access to principles but not to the full range of parameters. Schachter (1988) and Clahsen and Muysken (1989) have argued this case. It differs from the "indirect access" position in that it predicts that no evidence of "wild grammars" will be found.

Finally, the full access hypothesis claims that UG is an important causal factor in SLA, although not, of course, the only one. Those adopting the full access view [see: Flynn 1987; cited in White 2003] claim more than that the L1 UG affects the second language learning process. They claim that principles are not applicable to the second language learner's L1, but needed for the L2, will constrain the L2 learner's interlanguage. For example, the hierarchy principle of Subjacency, which constrains the kind of wh-movement permitted, is irrelevant to languages that lack wh-movement. While those adopting the partial access approach would claim that the Subjacency Principle would not affect a Korean native speaker learning English, since it is irrelevant to Korean, those taking a full access stance would expect the Subjacency principle to constrain, e.g., the Korean learner's interlanguage grammar.

In regard to parameter re-setting, the full access position, contrary to the partial access position, suggests that while the learner may pass through a stage where the L1 setting is applied to the L2, he will eventually attain the L2 setting, assuming a sufficient amount of relevant input.

\section{THE EMPIRICAL EVIDENCE}

The empirical evidence for the various positions that argue for some role for UG in the SLA process is mixed. Here are a few examples:

- a study by Ritchie [Ritchie 1978; cited in Ellis 1994] of Japanese students of English gave preliminary support to the assumption that linguistic universals are intact in the adult;

- White [White 1989; 2003] reports on a study of Japanese learners of English who, despite having no knowledge of question formation involving complex subjects, successfully acquired this knowledge in English. White argues that the learners must have had access to the principle of structural dependence; 
— Flynn [Flynn 1996; cited in Mitchell \& Myles 2004], reviewed research on Japanese learners of English, and claimed that it supported the view that UG constrains L2 acquisition;

- Thomas (1991) and White, Travis and Maclachlan (1992) both cited in Mitchell and Myles (2004) offer studies that also claim to support the full access to UG hypothesis;

— a study by Bley-Vroman, Felix and Ioup [Bley-Vroman, Felix, Ioup 1988; cited in Ellis 1994] of Korean learners of English concluded. Given the results, on the other hand, it is extremely difficult to maintain the hypothesis that Universal Grammar is accessible to adult learners;

— a study by Meisel [Meisel 1997; cited in Mitchell \& Myles 2004] of the acquisition of negation in French and German by L1 and L2 learners concludes that the UG principle of structure-dependency is not available to L2 learners;

- Schachter's (1989) test on Subjacency gave much more doubtful results than White's, which she says constitute a "serious challenge" to the claim that UG is available to adult learners.

\section{CONCLUSION}

In general, then, it seems that there is conflicting evidence for all positions, although Cook and Newson claim that "there is a great deal of evidence that knowledge of some aspect of language has been acquired in an L2 that is not learnable from input, that was not part of the learners' L1 and that is unlikely to have been taught by language teachers" according to Cook and Newson.

(C) Mahmoud Jabballa

Дата поступления: 22.12.2016

Дата принятия к печати: 25.01.2017

\section{REFERENCES}

1. Bley-Vroman, R. (1989). What is the logical problem of foreign language learning? In: S. Gass \& J. Schachter (Eds.), Linguistic perspectives on second language acquisition. p. $41-68$. Cambridge, UK: Cambridge University Press.

2. Clahsen, H. \& Muysken P. (1986). The availability of the Universal Grammar to adult and child learners: The study of acquisition of German word order. Second Language Research, 2, 93-113.

3. Cook, V. (1993). Linguistics and second language acquisition. New York: PALGRAVE.

4. Ellis, R. (1994). The study of second language acquisition. Oxford: OUP.

5. Felix, S. (1985). More evidence on competing cognitive systems see. Second Language Research, $1,47-72$.

6. Gregg, K. (1996) The logical and developmental problems of second language acquisition. In W. Ritchie \& T. Bhatia (Eds.), Handbook of second language acquisition. p. 49-81. San Diego: Academic Press.

7. Mitchell, R. \& Myles, F. (2004). Second language learning theories. 2nd ed. New York: OUP.

8. Meisel, J. (1997). The acquisition of syntax of negation in French and German: Contrasting first and second language development. Second Language Research, 13(3), 227-263.

9. Schachter, J. (1988). Second language acquisition and its relationship to Universal Grammar. Applied Linguistics, 9, 219-235. 
10. Schwartz, B. (1997). On the basis of the Basic Variety. Second Language Research, 13, 386-402.

11. Schwartz, B. \& Sprouse, R. (1996). L2 cognitive states and the full transfer/full access model. Second Language Research, 12, 40-72.

12. White, L. (1985). The pro-drop parameter in adult second language acquisition. Language Learning, 35, 47-62.

13. White, L. (2003). On the nature of interlanguage representation: Universal Grammar in the second language. In: C.J. Doughty \& M.H. Long (Eds.), The handbook of second language acquisition. p. 19-42). New York: Blackwell.

УДК: 372.881 .1

DOI: $10.22363 / 2313-2299-2017-8-2-479-484$

\title{
ОБ ОБОСНОВАНИИ ПРИНЦИПОВ ОСВОЕНИЯ ИНОСТРАННОГО ЯЗЫКА
}

\author{
Махмуд Мустафа Х. Джаббалла \\ Российский университет дружбы народов \\ ул. Миклухо-Маклая, 6, Москва, Россия, 117198
}

\begin{abstract}
В статье рассматриваются и обсуждаются различные точки зрения по вопросу об использовании принципов универсальной грамматики в процессе освоения иностранного (второго) языка взрослыми учащимися. Приводятся доводы за и против. Одним из важных принципов является решение вопроса отличается ли изучение иностранного языка от изучения родного языка или же оно осуществляется аналогичным образом. Исследователи процесса изучения иностранного языка с точки зрения лингвистических принципов решают этот вопрос в зависимости от того, применима или нет универсальная грамматика в процессе обучения к обоим языкам - родному и изучаемому. Поскольку все человеческие языки имеют общую природу, очевидно, что ответ будет положительным.
\end{abstract}

Ключевые слова: универсальная грамматика, освоение языка, приемлемость, гипотеза, фундаментальные сходства/различия

\section{БИБЛИОГРАФИЧЕСКИЙ СПИСОК}

1. Bley-Vroman, R. (1989). What is the logical problem of foreign language learning? In: S. Gass \& J. Schachter (Eds.), Linguistic perspectives on second language acquisition. p. 41-68. Cambridge, UK: Cambridge University Press.

2. Clahsen, H. \& Muysken P. (1986). The availability of the Universal Grammar to adult and child learners: The study of acquisition of German word order. Second Language Research, 2, 93-113.

3. Cook, V. (1993). Linguistics and second language acquisition. New York: PALGRAVE.

4. Ellis, R. (1994). The study of second language acquisition. Oxford: OUP.

5. Felix, S. (1985). More evidence on competing cognitive systems see. Second Language Research, 1, 47-72.

6. Gregg, K. (1996) The logical and developmental problems of second language acquisition. In W. Ritchie \& T. Bhatia (Eds.), Handbook of second language acquisition. p. 49-81. San Diego: Academic Press.

7. Mitchell, R. \& Myles, F. (2004). Second language learning theories. 2nd ed. New York: OUP.

8. Meisel, J. (1997). The acquisition of syntax of negation in French and German: Contrasting first and second language development. Second Language Research, 13(3), 227-263. 
9. Schachter, J. (1988). Second language acquisition and its relationship to Universal Grammar. Applied Linguistics, 9, 219-235.

10. Schwartz, B. (1997). On the basis of the Basic Variety. Second Language Research, 13, 386402.

11. Schwartz, B. \& Sprouse, R. (1996). L2 cognitive states and the full transfer/full access model. Second Language Research, 12, 40-72.

13. White, L. (1985). The pro-drop parameter in adult second language acquisition. Language Learning, 35, 47-62.

14. White, L. (2003). On the nature of interlanguage representation: Universal Grammar in the second language. In: C.J. Doughty \& M.H. Long (Eds.), The handbook of second language acquisition. p. 19-42). New York: Blackwell.

\section{Сведения об авторе:}

Махмуд Мустафа X. Джаббалла, аспирант кафедры общего и русского языкознания филологического факультета РУДН; e-mail: mahmoudm8911@mail.ru

\section{Bio Note:}

Mahmoud Mustafa H. Jabballa, Post-Graduate student at Department of General and Russian Linguistics at RUDN University; e-mail: mahmoudm8911@mail.ru 